\title{
Meiobenthos Assemblages as Bioindicators for Coastal Pollution Assessment
}

\author{
Tzachy Y. Morad*, Zvy Dubinsky, David Iluz \\ The Mina \& Everard Goodman Faculty of Life Sciences, Bar-Ilan University, Ramat-Gan, Israel \\ Email: ^tzachy.morad@gmail.com
}

How to cite this paper: Morad, T.Y., Dubinsky, Z. and Iluz, D. (2017) Meiobenthos Assemblages as Bioindicators for Coastal Pollution Assessment. Open Journal of Marine Science, 7, 409-423. https://doi.org/10.4236/ojms.2017.73028

Received: August 15, 2016

Accepted: July 10, 2017

Published: July 13, 2017

Copyright @ 2017 by authors and Scientific Research Publishing Inc. This work is licensed under the Creative Commons Attribution International License (CC BY 4.0).

http://creativecommons.org/licenses/by/4.0/ (c) (i) Open Access

\begin{abstract}
Coastal pollution assessment is a pressing matter as the anthropogenic pressure continues to increase worldwide. A leading approach to assess coastal pollution is using bioindicators. However, identifying species is time-consuming and demands profound morphological knowledge. Our goal was to find the meiobenthic composition in each pollution level. By utilizing the meiobenthic assemblage's ratios, we will be able to indicate the pollution level. We examined the meiobenthos distribution at three sites exposed to a pollution gradient. We quantified the changes in the fauna assemblage in the community phylum level, focusing on nematodes and foraminifera (90\% of the total population). Over 400 samples were examined, covering an annual seasonal cycle. Nematodes population dominated in the polluted coast. Nematodes density increased with the pollution level, up to seemingly harmful levels of pollution. In contradiction, the foraminifera flourished in the control site and exhibited an inverse relationship to the nematodes. We witnessed drastic changes in the entire meiobenthic population in the winter, which we speculate that originated from winter turbulences. We suggest that nematodes-foraminifers' population ratios may be utilized as bioindicators for assessing coast intertidal zone pollution levels.
\end{abstract}

\section{Keywords}

Meiobenthos, Bioindicator, Coast, Nematode, Foraminifera, Pollution

\section{Introduction}

The shores of the Mediterranean contain a variety of environments populated by different species that have adapted themselves to the different niches [1]. The semienclosed basin and the climate lead to barren conditions particularly in the southeast region, the Levantine Sea. Higher temperatures and higher evaporation that, in turn, cause the sea level to decrease and the salinity to increase from 
west to east characterizes the climate in the Levantine Sea. The Mediterranean basin is generally oligotrophic except for its coastal regions, which change due to wind, thermoclines, currents, rivers, and anthropogenic factors. These oceanographic conditions cause spatial patterns of decrease in biodiversity and primary production from northwest to southeast [2].

Furthermore, eastern Mediterranean biodiversity is under severe pressure caused by Lessepsian migration and global warming. The opening of the Suez Canal opened a doorway between the Red Sea and the Mediterranean that resulted in the migration of hundreds of tropical species towards the Mediterranean Sea. These species inhibit the Mediterranean and push aside the local fauna. This situation is amplified by the constant increase in seawater temperature. The increase assists the adaptation of migrating subtropical species and contributes to the "tropicalization" of the basin [2] [3] [4] [5] [6]. These changes in turn, have a tremendous effect on the biology and ecology of the indigenous organisms in the Levantine Sea [2].

The coastal area is generally considered the most prosperous area in the basin, which brought human population to set up their homes in close proximity to the coastline. Today, more than $40 \%$ of the world's population lives within a range of $100 \mathrm{~km}$ from the coastline. By 2025, the population near the coastline is predicted to exceed $50 \%$ of the total global population [2] [7]. This leads to a heavy anthropogenic pressure on the coastal ecosystem, which constantly increases as a result of human development along the coasts. This leads to the substantial and pressing matter of the assessment of pollutants and their effect on all organisms and on the different ecosystems in the coastal area [8] [9] [10].

In the coastal ecosystem, the marine soil is an important key factor that regulates the entire ecosystem. It functions as a food and mineral source, breeding ground, protective layer, camouflage, and buffer zone [11]. Soil characteristics, along with biotic and abiotic factors, determine the composition of the epifauna, infauna, and pelagic populations in a direct and indirect fashion [12]. Accordingly, we hypothesize that by comparing the population composition between coasts we would be able to evaluate coastal pollution levels. We assumed that biological indicators (bioindicators) among the meiobenthic fauna of clean and polluted coasts maintain a relation, which we could use to determine the intertidal coastal region pollution levels. We sought to determine which organisms are best suited to be bioindicators and can be utilized more efficiently to evaluate coasts pollution levels. For that purpose, we looked for bioindicators who are easy to extract and in sufficient amounts for statistical analysis. To identify organisms that are suitable as bioindicators we compared the meiobenthic (benthic organisms that were retained by passing through a $63-1000 \mu \mathrm{m}$ mesh) population composition in polluted and clean rocky coasts [9] [13] [14] [15] [16].

\section{Material and Methods}

\subsection{Study Sites}

The research was conducted in the Levantine Sea, in the southeastern basin of 
the Mediterranean Sea, along the coastline of Israel. Three rocky coasts re-presenting a pollution gradient along a $28 \mathrm{~km}$ strip, were selected according to $\mathrm{He}$ rut et al. (2014), Herut et al. (2015), Hoffman et al. (2011) and personal communication $^{1}$ [17] [18] [19]. Of the three coasts, the most polluted one was Jisr ez-Zarqa (Za, $\left.32^{\circ} 37^{\prime} 14.33^{\prime \prime} \mathrm{N}, 34^{\circ} 55^{\prime} 2.84^{\prime \prime} \mathrm{E}\right)$, followed by Mikhmoret (Mi, $\left.32^{\circ} 24^{\prime} 15.90^{\prime \prime} \mathrm{N}, 34^{\circ} 51^{\prime} 59.20^{\prime \prime} \mathrm{E}\right)$ coast, and the cleanest coast was Nahsholim (Na, $\left.32^{\circ} 32^{\prime} 23.01^{\prime \prime N}, 34^{\circ} 54^{\prime} 5.88^{\prime \prime} \mathrm{E}\right)$. The Za coast is located at the estuary of the Crocodile Stream, while the Mi coast is located in close proximity to the Alexander River and a marina. In both water sources the main pollutants are agriculture and sewage residues. The sampling sites were in semi-enclosed areas (near rocks and rock tables), with the lowest water inflow possible. Those coasts were sampled and monitored every other month between July 2013 and September 2014 (if the sea conditions allowed), when the lowest amplitude between the neap and spring tides was present (first and third quarter of the moon cycle).

\subsection{Sampling}

Meiobenthic core samples were collected from sandy areas parallel to the coastline at a $0.5 \mathrm{~m}$ depth and with $0.5 \mathrm{~m}$ intervals between samples. The core samples were taken by inserting $150 \mathrm{ml}$ plastic cups ( $n=5-14,5.5 \mathrm{~cm}$ diameter, 6.8 $\mathrm{cm}$ in length) into the soil. The cores were then capped and maintained in a dark cooler with water and ice until they were transported to the lab. We chose to identify the organisms to the phylum level. The average size of meiobenthos in close proximity to the coast didn't exceed $1 \mathrm{~mm}$. Thus, recognition of species according to the morphology was a time consuming task. Thus, choosing to focus on the phylum level allowed us to analyze more samples in shorter time.

\subsection{Environmental Parameters}

The abiotic parameters of the water, including temperature $(\mathrm{t}), \mathrm{pH}$, salinity $(\mathrm{S})$, conductivity, oxygen concentration, oxygen saturation, oxidation reduction potential, specific resistance, partial pressure, and total dissolved solids, were monitored at each coast using a WTW Multi 3430 Multiparameter Meter equipped with SenTix 940, TetraCon 925, and FDO 925 sensors (WTW GmbH, Weilheim, Germany).

\subsection{Organism Preservation}

From January to September 2014, an amount of $5 \mathrm{~cm}^{3}$ soil from each sample was placed in a $15 \mathrm{ml}$ conical tube and stained with $5 \mathrm{ml}$ of Rose Bengal solution $\left(\mathrm{g} \cdot \mathrm{l}^{-1}\right)$. The samples were stored for at least 10 days before counting and classifying the different phyla under a stereo microscope. Foraminiferal samples of dominant species were examined and identified to the genus or species level, when possible.

A volume of $30 \mathrm{~cm}^{3}$ soil from each sample was inserted into a $50 \mathrm{ml}$ centrifuge

${ }^{1}$ According to unpublished data from the labs of Prof. Barak Herut and Dr. Gil Rilov of Israel Oceanographic and Limnological Research (IOLR). 
tube and mixed with formaldehyde solution (4\% formaldehyde, $96 \%$ artificial seawater) using a vortex; the rest of the sample was taken for organic-matter $(\mathrm{OM})$ analysis. After $48 \mathrm{~h}$, the solution was poured out and replaced with ethanol solution (70\% ethanol, 30\% artificial seawater) for preservation and storage. Extraction was initiated by pouring the sample into a $63 \mu \mathrm{m}$ sieve and gently rinsing it with tap water. A volume of $30 \mathrm{~cm}^{3}$ of soil was taken from the sample and placed into a $50 \mathrm{ml}$ conical tube. The sample was processed and its meiobenthos were extracted according to Burgess (2001) [20], and stored in a $50 \mathrm{ml}$ conical tube with $70 \%$ ethanol solution. The organisms were stained with 1 drop of Rose Bengal solution ( $5 \mathrm{~g} \cdot \mathrm{l}^{-1}$ ) per $5 \mathrm{ml}$ of sample solution. The samples were stored for at least one week before being sieved through a filter and analyzed under stereo microscope.

All organisms were identified to the phylum level according to Atkins (2002), Murray (2006), Guilini (2017), and Ridel (2010) [12] [21] [22] [23].

\subsection{Soil Analysis}

Each of the samples was processed according to Eleftheriou \& McIntyre (2005) and Avnimelech et al. (2001) [24] [25]. According to "loss on ignition" method, the samples were oven-dried at $70^{\circ} \mathrm{C}$ for at least $48 \mathrm{~h}$. They were then weighed and placed in an oven set to $390^{\circ} \mathrm{C}$ for $8 \mathrm{~h}$, and the lost weight was calculated to OM percentage. Porosity was measured under the assumption that the water density was $1 \mathrm{~g} \cdot \mathrm{cm}^{-3}$. Soil size fractions were measured by screening with a mechanical sieve shaker through $63 \mu \mathrm{m}, 125 \mu \mathrm{m}, 250 \mu \mathrm{m}, 500 \mu \mathrm{m}$, and $1000 \mu \mathrm{m}$ sieves.

\section{Results and Discussion}

The present study is among the few focusing on the effects of pollution on meiobenthic populations in the intertidal area of the southeastern basin of the Mediterranean. The study also examined the seasonal changes on the meiobenthic populations. The samples indicated a high presence (over $90 \%$ of the organisms in each sample) of nematode, foraminiferal, and annelid populations. The rest of the phyla were present in negligible numbers and, therefore, were not included in this study. Furthermore, a high variability in the number of organisms among samples, which caused a significant standard deviation, was observed in each coast. In our attempt to overcome this problem, we raised the number of samples at each site to up to 14 . This attempt was not successful, as no significant reduction in standard deviation was observed. This led us to realize the mosaic-like nature of the complex, observed ecosystems, which are characterized by patchy population distribution. Future work would require a reduction of the number of samples and a concomitant increase in the size of each sample to at least $10 \mathrm{~cm}$ diameter [24].

When we evaluated the variety of organisms at the three coasts, a few trends became obvious. There was an opposite relationship between the nematode and foraminiferal assemblages ( $\mathrm{t}$ test $(p<0.05),-0.556$, Spearman rho $(p<0.05))$ : a 
growth in the number of nematodes was accompanied by a decline in the number of foraminifera, and vice versa. This situation can imply a prey-predator relationship, competition over resources, antibiosis, or a combination of these. This assumption is strengthened by previous studies. Evidence for a prey-predator relationship was found in a number of works on both nematodes and foraminifera. Furthermore, both taxa were described as "opportunists" that could change their nutritional habits or feed on a number of food sources [12] [22] [26] [27] [28]. In addition, the nematodes themselves can produce dissolved organic material that can be utilized by other fauna, like foraminifera [12]. The dominant foraminifera at all of the coasts were Ammonia sp., Amphistegina lobifera, and Pararotalia calcariformat (Sorites orbiculus and Quinqueloculina sp. were also present, but in far lower numbers). A study of the foraminiferal species Ammonia beccarii (which is common throughout the Mediterranean and the dominant genus in all our samples) found that it consumed a substantial amount of algae and bacteria and thereby reduced the numbers of other populations (e.g., nematodes), depending on them as a food source [22] [26]. The mentioned studies support our assumption for an inverse relationship.

We could also see that the foraminiferal population fluctuated with the seasons (Figure 1). This pattern was also evident when we examined each individual coast, with peaks in January, May, and September. When the highest peaks were around the cold season (January and September). We assume that this increase might be part of a distribution strategy in which the foraminifera utilizes the big waves and strong currents of the winter to reach new, faraway environments. This strategy is even more important in an area with very weak tidal forces, such as the eastern Mediterranean costal area [29] [30] [31] [32].

However, when we focused on each individual coast, new trends became evident. At the Na coast (Figure 1(a)), there was an almost-complete domination of foraminifera over the nematodes (a minimum of 8.82 oragnisms $\cdot \mathrm{cm}^{-3}$ difference in favor of the foraminifera), reaching its peak at the end of the summer $\left(74.26\right.$ organisms $\left.\cdot \mathrm{cm}^{-3}\right)$. The Na coast is consistently characteristic of subtropical areas, in which population growth reaches its peak in late summer [12]. When we looked at the nematode population, we could see that in the $\mathrm{Na}$ coast, this population increased in the winter $\left(12.28\right.$ organisms $\left.\cdot \mathrm{cm}^{-3}\right)$ but remained at a low basal level for the rest of the year. Comparison with the other shores supports our assumption that there are reciprocal relations between the two populations. The domination of the foraminifera over nematodes is not common [12] [22] and, in most cases, the nematodes in sandy marine soils are the dominant taxa among the benthic population throughout the year. We assume that this niche of the intertidal zone that is affected by constant waves and currents and suppressed by rocks and rock tables is best suited for the foraminifera. The mild but constant currents that bring fresh oxygen and nutrients to the top layers of the sediment are ideal, allowing the foraminifera to flourish and become dominant over the nematodes. The annelids (Figure 2) did not appear to have any notable relationship with the other populations. However, we could see a population 


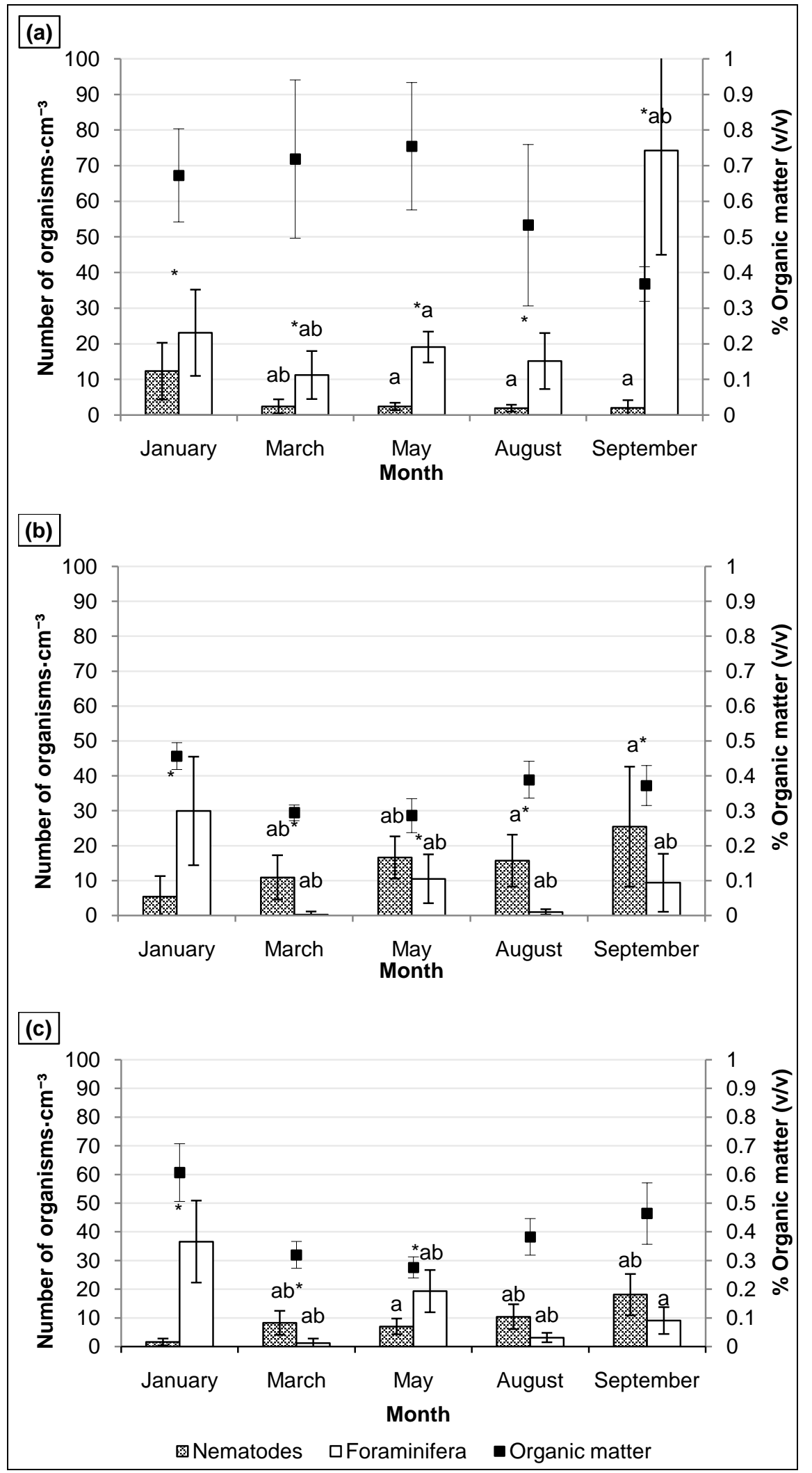

Figure 1. Nematode, foraminifera, and OM average $(n=6-14)$. The samples were taken at $\mathrm{Na}$ (a), Mi (b), and $\mathrm{Za} \mathrm{(c)} \mathrm{coasts} \mathrm{in} \mathrm{each} \mathrm{sampling} \mathrm{from} \mathrm{January} \mathrm{to} \mathrm{September} 2014$. Significant to January (a), previous month (b) and between nematode and foraminifera $\left.{ }^{*}\right)$ according to $t$ test $p<0.05$. 


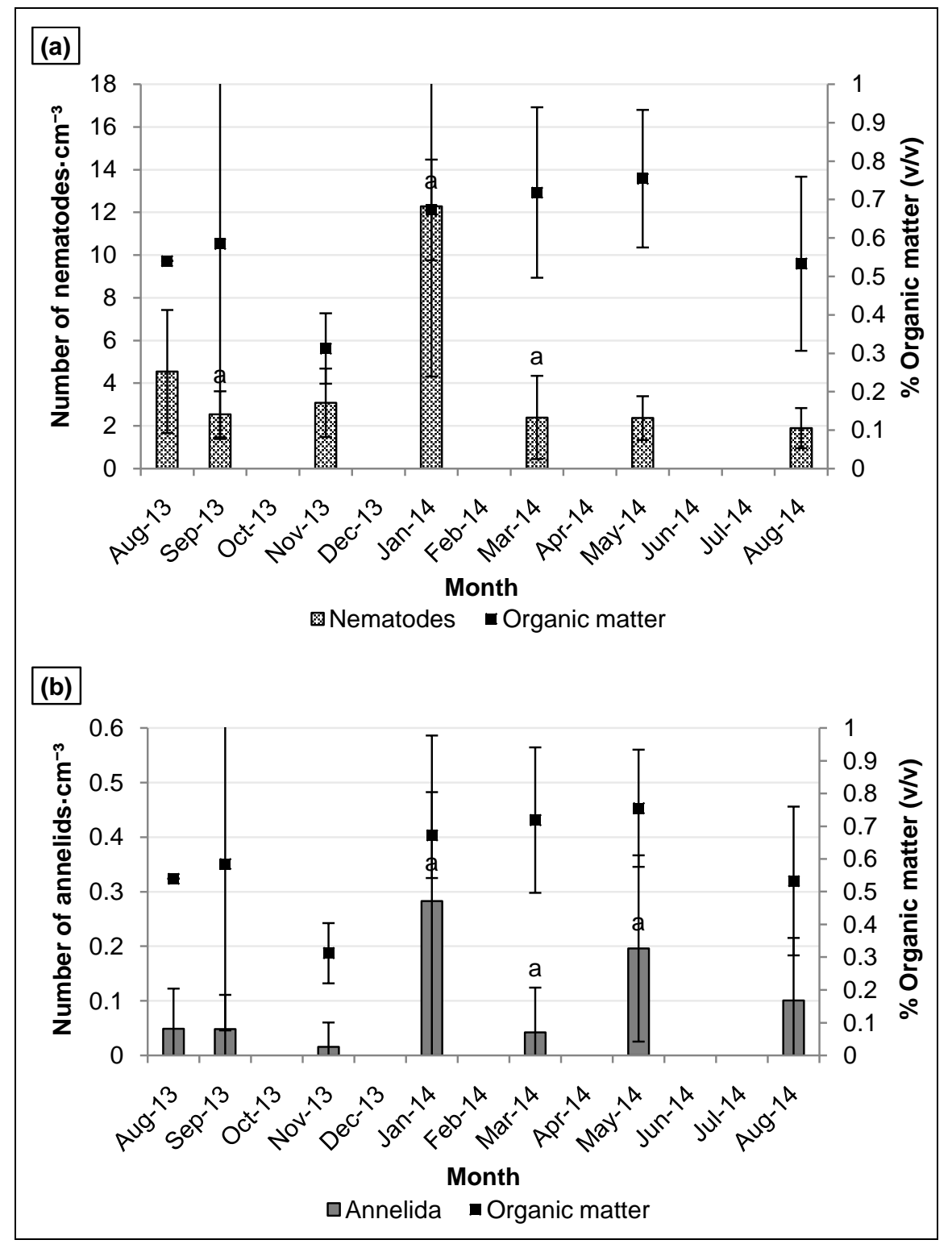

Figure 2. Nematodes (a) annelids (b) and OM average $(n=6-14)$ at $\mathrm{Na}$, from August 2013 to August 2014. Significant to previous month (a) according to t test $p<0.05$.

peak in the winter (as was the case with the nematodes) and a subsequent reduction in the population's size compared to the previous year.

At the Mi coast, the trend was reversed (Figure 1(b)): foraminiferal dominance in the winter (24.54 oragnisms $\cdot \mathrm{cm}^{-3}$ difference in favor of the foraminifera) decreased with increased growth of the nematode population (as the temperature rose) towards the summer. The Mi nematode population was also the biggest of all the coasts and reached a peak of 25.42 oragnisms $\cdot \mathrm{cm}^{-3}$. We assume that a pollutant in this area drives down the foraminiferal population and clears the niche for the nematodes to thrive or that organic enrichment supports the nutrition of the nematodes directly [33] or indirectly (by increasing the algal or bacterial population). The annelid population (Figure 3 ) showed a successive growth cycle throughout the year; however, the population size did not return to 


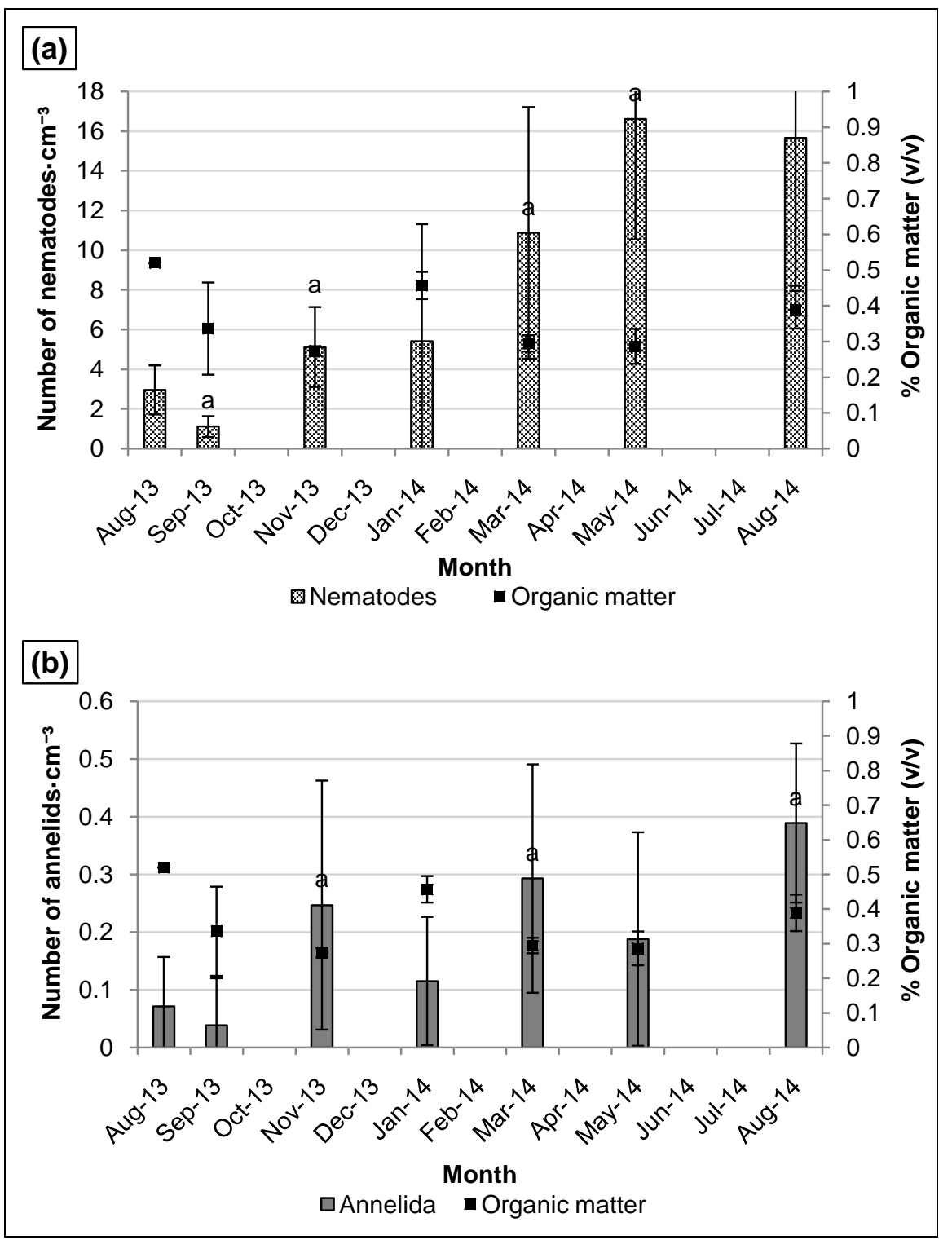

Figure 3. Nematodes (a) annelids (b) and OM average ( $n=6-14)$ at Mi, from August 2013 to August 2014. Significant to previous month (a) according to $t$ test $p<0.05$.

its original size of the previous year. We assume the cause for this is a pollutant or other significant disturbances in the summer of 2013.

The Za coast meiobenthic distribution resembled that of the Mi coast (Figure $1(c)$ ). The $\mathrm{Za}$ nematode population increased towards the summer but was almost half the size of the nematode population on the Mi coast. The change in size of the foraminiferal population was also similar to that of the Mi population but the population size was bigger in $\mathrm{Za}$. The annelids in $\mathrm{Za}$ coast (Figure 4) reached their highest population peak (March, 0.51 oragnisms $\cdot \mathrm{cm}^{-3}$ ) but its population size remained very small most of the year.

Utilization of population ratios is a known approach for biomonitoring of the environment. Nematode-copepod ratios have been used in the past to assess different pollutants. However, nematode-foraminifera ratios have been mostly 


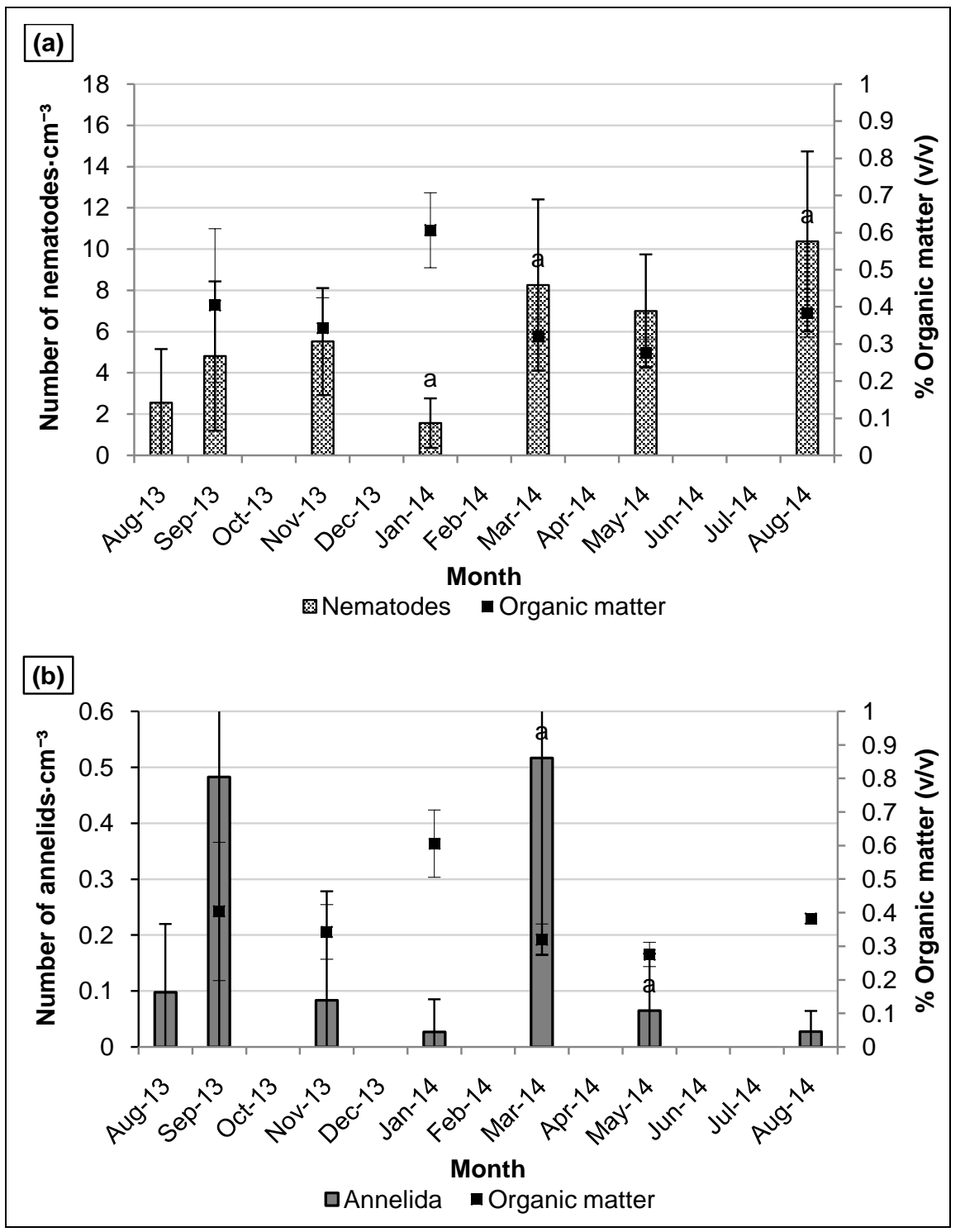

Figure 4. Nematodes (a) annelids (b) and OM average $(n=6-14)$ at $\mathrm{Za}$, from August 2013 to August 2014. Significant to previous month (a) according to t test $p<0.05$.

overlooked [34] [35] [36]. The similarity with population ratios between the Mi and $\mathrm{Za}$ coasts led us to the assumption that, in their natural state (e.g., $\mathrm{Na}$ coast), the foraminifera dominate the intertidal coastal rocky area. However, when the coastal waters are subject to anthropogenic factors, the pollutant-sensitive foraminifera decrease in numbers and let the more resistant nematodes flourish [12], [22] [33] [37]. This condition is even more significant considering our assumption regarding the predator-prey relationship of the foraminifera and the nematodes. It was also obvious to see that anthropogenic factors not only change the ratios but also the growth cycles (Figure 1). It appears that in their natural state, the foraminifera grow in numbers towards the end of the summer while the number of nematodes increased in the winter, but the cycles have changed in the polluted coasts. The foraminiferal population increased only in the winter but it was also noticeable that there were growth peaks every 4 months. The nema- 
todes in the polluted beach have completely changed their growth pattern and stopped showing any noticeable seasonal cycle. On the other hand, they grew in numbers towards the end of summer with the increase in temperature. This led us to the realization that the anthropogenic factors caused constant reproduction within the nematode population and, as the temperature rose, the conditions became more ideal for them to flourish. We also suggest that the pollution-sensitive foraminifera reproduce more significantly in the winter at polluted coasts as a result of the high turbulence in the sea at that time. The strong, turbulent oceanographic conditions in the winter dilute the pollution in the water column and in the soil by distributing the pollution homogeneously around the coastal line while, at the same time, they enrich the water and soil with organic particles. Those conditions facilitate the reproduction and distribution of foraminiferal gametes [38] [39]. When we evaluated the foraminifera-nematode ratio we saw that while in the winter the ratio average is above $\sim 4$ in all coasts (with no significate difference between coasts, $p<0.05)$. In the summer, Na coast was significantly higher $(\sim 23$ ratio in average, $p<0.05)$ than the rest of the coasts $(\sim 0.41$ ratio average). Thus, the ratio indicates the level of coast cleanliness, the higher the number, the less polluted the coast is.

We evaluated the diversity of the population at each coast (Table 1) according to the Simpson index. While the Mi coast did not show any significant trend, the $\mathrm{Na}$ and $\mathrm{Za}$ coasts showed opposing results. Although stress on the ecosystem commonly causes a decline in diversity. In January, the Simpson index at the $\mathrm{Na}$ coast was the lowest while at $\mathrm{Za}$ it was the highest. In the following months, the Simpson index at $\mathrm{Na}$ increased while at $\mathrm{Za}$ it declined. These results strengthen our assumption that, in the winter, the harsh weather and oceanographic conditions dilute pollution in the polluted coasts which, in turn, causes a steep increase in the reproduction of the entire community and, in turn, increases the entire coastal diversity. This increase in diversity is not maintained for long: the coasts slowly return to their polluted state while diversity declines with the increase in pollution. Hence, the winter season restores the natural state. We suggest that this repeating renewal acts as a buffer that prevents pollution tolerant species from overtaking this niche from native species [40]. At the Na coast, winter has the opposite effect: it brings change to the stable community, and the organic enrichment does not have a positive effect, which lowers the diversity of the entire community.

Table 1. Simpson's diversity index for the nematode, foraminiferal, and annelid populations in all coasts from January to September 2014.

\begin{tabular}{cccccc}
\hline \multicolumn{1}{c}{ Month } & January & March & May & August & September \\
\hline Nahsholim & 0.53025 & 0.699969 & 0.779154 & 0.881065 & 0.948944 \\
Mikhmoret & 0.722352 & 0.899955 & 0.500216 & 0.688553 & 0.594867 \\
Zarqa & 0.916413 & 0.664822 & 0.590617 & 0.476568 & 0.538559 \\
\hline
\end{tabular}


When we looked at the OM at each coast (Figures 1-4), we saw that there was a similar seasonal cycle of the $\mathrm{OM}$ in $\mathrm{Mi}$ and $\mathrm{Za}$ coasts but a different $\mathrm{OM}$ cycle in $\mathrm{Na}$ coast. Both polluted coasts ( $\mathrm{Mi}$ and $\mathrm{Za}$ ) exhibited an increase in $\mathrm{OM}$ in January and August while, at the clean coast $(\mathrm{Na})$, we observed an increase only in January (that increase was maintained and even grew until the summer). Surprisingly, the OM amounts were higher at the clean coast compared to the polluted ones, opposite to the nematode assemblages. These observations led us to the conclusion that the nematodes that thrive in the polluted coasts feed on the $\mathrm{OM}$ and act as biofilters; therefore, this population grows as the OM declines.

If we compare the porosity in the different populations (Figure 5), we can see that at the $\mathrm{Na}$ coast, there is a correlation between the average number of foraminifera and the average total number of all organisms to the porosity. We also noticed a weak correlation the nematodes and the porosity. These relationships weaken as the level of pollution increases. In addition, porosity declines as the pollution level rises. While all fauna can increase porosity in the soil, the nematodes play a greater role. The saliva that the nematodes produce acts as a glue that strengthens the burrows that the nematodes leave in their tracks. These stable burrows significantly increase the porosity of the soil. This ability, along with the high mobility of the nematodes, renders them much less affected by the natural porosity of the soil and explain their anoxia tolerances [12] [41] [42] [43]. This data suggests that while the increase in porosity in the natural state allows the meiobenthos to flourish and expand deeper into the soil, pollution halts the population's ability to do so and, as a result, general porosity remains low. However, the resilient nematodes are not affected by both of these factors and they can flourish until the level of pollution will halt their growth as well.

\section{Conclusions}

The meiobenthic population showed a dramatic change in numbers and in growth cycles, as the pollution levels rose. The winter climate assisted in diluting the pollution, which, in turn, shifted the coastal community and reinstated the natural community state. The winter acted as a buffer which offered the community time to revert to the natural state. At the same time, hindered pollution resilient meiobenthic species completely overtake this habitat. The foraminifera showed significant sensitivity to pollution while the nematodes were more resilient (as were the annelids) and thus became dominate. We suggest that pollutants harm the foraminifera while changing the natural food sources available. This provides the nematodes, which can thrive on diverse food sources, a competitive advantage. Therefore, we propose that the nematodes and foraminifera can be reliable bioindicators of polluted coasts. Furthermore, the nematode-foraminifers' ratio can be utilized for a costal cleanliness evaluation.

Future research should study the changes that occur at the species or genus level while monitoring pollutants on a monthly basis. When we will be able to better quantify the level of pollution and how it affects the nematode-foraminifers' ratio we will be able to associate and evaluate the conditions of the different 


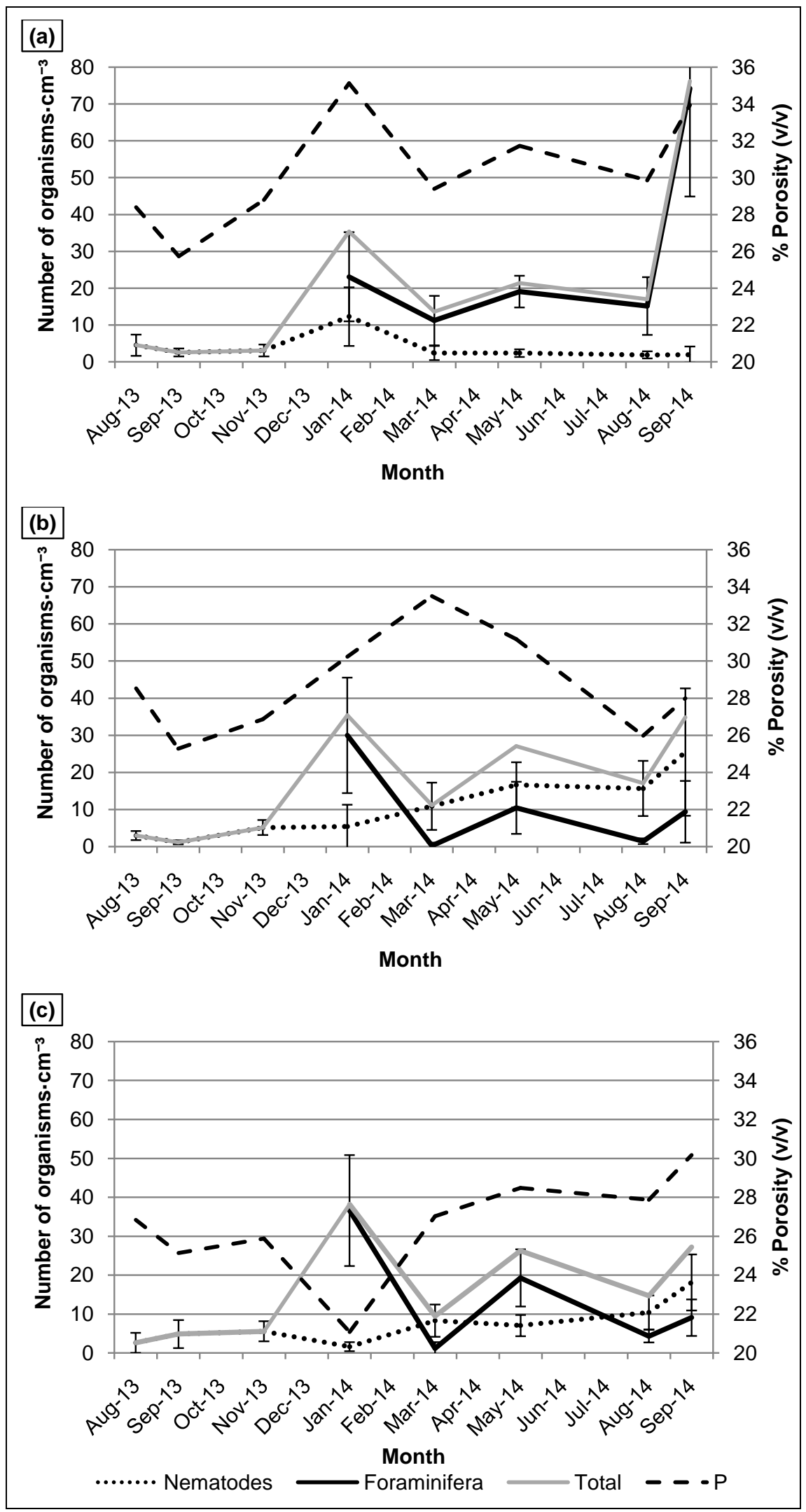

Figure 5. Average ( $n=6-14$ ) of soil porosity, nematodes, foraminifera and the total of organisms extracted in each sampling. The samples were taken at $\mathrm{Na}(\mathrm{a}), \mathrm{Mi}(\mathrm{b})$ and $\mathrm{Za}$ (c) coasts from August 2013 to September 2014. 
coasts. We suggest that a metagenomic approach be used. The knowledge required and the time-consuming methods of extraction and identification by morphology are likely to cause errors throughout the study.

\section{Acknowledgements}

The use of data sets from the labs of Prof. Barak Herut and Dr. Gil Rilov, from Israel Oceanographic and Limnological Research Institution, is gratefully acknowledged. We also want to acknowledge the financial aid from Israel Ministry of Agriculture \& Rural Development. We would like to thank Dr. Ahuva Almogi for assisting with the classification of the foraminifera and Dr. Yuri Kamenir with the statistics analysis. Lastly, we want to thank Sharon Victor and Roni Hendler for editing the manuscript.

\section{References}

[1] Dahl, E. (1952) Some Aspects of the Ecology and Zonation of the Fauna on Sandy Beaches. Oikos, 1923, 1-27.

[2] Coll, M., Piroddi, C., Steenbeek, J., Kaschner, K., Lasram, F.B.R., Aguzzi, J., Ballesteros, E., Bianchi, C.N., Corbera, J., Dailianis, T., Danovaro, R., Estrada, M., Froglia, C., Galil, B.S., Gasolm J.M., Gertwage, R., Gil, J., Guilhaumon, F., Kesner-Reyes, K., Kitsos, M.S., Koukouras, A., Lampadariou, N., Laxamana, E., de la Cuadra, C.M.L.F., Lotze, H.K., Martin, D., Mouillot, D., Oro, D., Raicevich, S., Rius-Barile, J., Saiz-Salinas, J.I., Vicente, C.S., Somot, S., Templado, J., Turon, X., Vafidis, D., Villanueva, R., and Voultsiadou, E. (2010) The Biodiversity of the Mediterranean Sea: Estimates, Patterns, and Threats. PLoS ONE, 5, e11842. https://doi.org/10.1371/journal.pone.0011842

[3] Por, F.D. (1971) One Hundred Years of Suez Canal-A Century of Lessepsian Migration: Retrospect and Viewpoints. Systematic Zoology, 20, 138-159. https://doi.org/10.2307/2412054

[4] Por, F.D. (1975) Pleistocene Pulsation and Preadaptation of Biotas in Mediterranean Seas: Consequences for Lessepsian Migration. Systematic Zoology, 24, 72-78. https://doi.org/10.2307/2412699

[5] Golani, D. (1998) Impact of Red Sea Fish Migrants through the Suez Canal on the Aquatic Environment of the Eastern Mediterranean. Bulletin Series Yale School of Forestry and Environmental Studies, 103, 375-387.

[6] Lejeusne, C., Chevaldonné, P., Pergent-Martini, C., Boudouresque, C.F. and Pérez, T. (2010) Climate Change Effects on a Miniature Ocean: The Highly Diverse, Highly Impacted Mediterranean Sea. Trends in Ecology and Evolution, 25, 250-260. https://doi.org/10.1016/j.tree.2009.10.009

[7] Jean, P.G. and Stephen, V.S. (2011) Coastal Zone. [Online]. Available: http://editors.eol.org/eoearth/wiki/coastal_zone

[8] Simboura, N. and Zenetos, A. (2002) Benthic Indicators to Use in Ecological Quality Classification of Mediterranean Soft Bottom Marine Ecosystems, including a New Biotic Index. Mediterranean Marine Science, 3, 77-111. https://doi.org/10.12681/mms.249

[9] Rosenberg, R., Blomqvist, M., Nilsson, H.C., Cederwall, H. and Dimming, A. (2004) Marine Quality Assessment by Use of Benthic Species-Abundance Distributions: A Proposed New Protocol within the European Union Water Framework Directive. Marine Pollution Bulletin, 49, 728-739. 
[10] Armenteros, M., Regadera, R., Vincx, M. and Decraemer, W. (2009) Effects of Chronic and Heavy Pollution on Macro- and Meiobenthos of Havana Bay, Cuba. Revista de Investigacion Marina, 30, 203-214.

[11] Glibert, P.M., Burkholder, J.M. and Kana, T.M. (2012) Recent Insights about Relationships between Nutrient Availability, Forms, and Stoichiometry, and the Distribution, Ecophysiology, and Food Web Effects of Pelagic and Benthic Prorocentrum Species. Harmful Algae, 14, 231-259.

[12] Giere, O. (2009) Meiobenthology. The Microscopic Motile Fauna of Aquatic Sediments. 2nd Edition, University of Hamburg. Springer-Verlag, Berlin, Heidelberg.

[13] Borowitzka, M. (1972) Intertidal Algal Species Diversity and the Effect of Pollution. Australian Journal of Marine and Freshwater Research, 23, 73-84. https://doi.org/10.1071/MF9720073

[14] Pinedo, S., Garcia, M., Satta, M.P., de Torres, M. and Ballesteros, E. (2007) RockyShore Communities as Indicators of Water Quality: A Case Study in the Northwestern Mediterranean. Marine Pollution Bulletin, 55, 126-135.

[15] Balsamo, M., Semprucci, F., Frontalini, F. and Coccioni, R. (2010) Meiofauna as a Tool for Marine Ecosystem Biomonitoring. In: Cruzado, A., Ed., Marine Ecosystems, InTech.

[16] Holt, E.A. and Miller, S.W. (2011) How Do We Assess the Impacts of Human Activities on Natural Ecosystems? What Can the Biota Tell Us about the Environment and Its Response to Natural Stress? Introduction What Is a Bioindicator? Nature Education Knowledge, 2, 1-10.

[17] Herut, B., Shefer, E., Gordon, N., Galil, B., Lubinevsky, H., Tibor, G., Tom, M., Rilov, G., Silverman, J. and Rinkevich, B. (2014) The National Monitoring Program of Israel's Mediterranean Coastal Waters. Scientific Report for 2012, IOLR Report H62/2013.

[18] Herut, B. and All Scientific Group of IOLR, National Institute of Oceanography (2015) The National Monitoring Program of Israel's Mediterranean waters. Scientific Report for 2013/14, IOLR Report H21/2015.

[19] Hoffman, A., Iluz, R., Kamenir, D., Dubinsky, Y. and Israel, Z. (2011) Pollution Effects on the Benthic Intertidal Algal Flora along the Israeli Mediterranean Shores. Bar Ilan University, Ramat Gan.

[20] Burgess, R. (2001) An Improved Protocol for Separating Meiofauna from Sediments Using Colloidal Silica Sols. Marine Ecology Progress Series, 214, 161-165. https://doi.org/10.3354/meps214161

[21] Guilini, K., Bezerra, T.N., Eisendle-Flöckner, U., Deprez, T., Fonseca, G., Holovachov, O., Leduc, D., Miljutin, D., Moens, T., Sharma, J., Smol, N., Tchesunov, A., Mokievsky, V., Vanaverbeke, J., Vanreusel, A., Venekey, V. and Vincx, M. (2017) NeMys: World Database of Free-Living Marine Nematodes. Accessed at http://nemys.ugent.be

[22] Murray, J.W. (2006) Ecology and Applications of Benthic Foraminifera. Cambridge University Press, New York, 1-426.

[23] Ridel, R. (2010) Fauna and Flora of the Mediterranean. Seifert Verlag.

[24] Eleftheriou, A. and Mcintyre, A. (2005) Methods for Study of Marine Benthos. 3rd Edition, Vol. 1004, Blackwell Science, Hoboken, NJ.

https://doi.org/10.1002/9780470995129

[25] Avnimelech, Y., Ritvo, G., Meijer, L.E. and Kochba, M. (2001) Water Content, Organic Carbon and Dry Bulk Density in Flooded Sediments. Aquacultural Engineering, 25, 25-33.

[26] Dupuy, C., Rossignol, L., Geslin, E. and Pascal, P.-Y. (2010) Predation of Mudflat 
Meio-Macrofaunal Metazoans by a Calcareous Foraminifer, Ammonia Tepida (Cushman, 1926). The Journal of Foraminiferal Research, 40, 305-312.

[27] Moens, T., Herman, P., Verbeeck, L., Steyaert, M. and Vincx, M. (2000) Predation Rates and Prey Selectivity in Two Predacious Estuarine Nematode Species. Marine Ecology Progress Series., 205, 185-193. https://doi.org/10.3354/meps205185

[28] Moens, T. and Vincx, M. (1997) Observations on the Feeding Ecology of Estuarine Nematodes. Journal of the Marine Biological Association of the United Kingdom, 77, 211-227. https://doi.org/10.1017/S0025315400033889

[29] Johannes, R.E. (1978) Reproductive Strategies of Coastal Marine Fishes in the Tropics. Environmental Biology of Fishes, 3, 65-84.

[30] Peterson, W. (1998) Life Cycle Strategies of Copepods in Coastal Upwelling Zones. Journal of Marine Systems, 15, 313-326.

[31] Pringle, J.M., Byers, J.E., Pappalardo, P., Wares, J.P. and Marshall, D. (2014) Circulation Constrains the Evolution of Larval Development Modes and Life Histories in the Coastal Ocean. Ecology, 95, 1022-1032. https://doi.org/10.1890/13-0970.1

[32] Robins, P.E., Neill, S.P., Giménez, L., Jenkins, S.R., Malham, S.K. and Gime, L. (2013) Physical and Biological Controls on Larval Dispersal and Connectivity in a Highly Energetic Shelf Sea. Limnology and Oceanography, 58, 505-524. https://doi.org/10.4319/lo.2013.58.2.0505

[33] Wang, J., Zhou, H., Zhang, Z., Cong, B. and Xu, S. (2011) Effects of Organic Enrichment on Sandy Beach Meiofauna: A Laboratory Microcosm Experiment. Journal of Ocean University of China, 10, 246-254. https://doi.org/10.1007/s11802-011-1831-4

[34] Amjad, S. and Gray, J.S. (1983) Use of the Nematode-Copepod Ratio as an Index of Organic Pollution. Marine Pollution Bulletin, 14, 178-181.

[35] Coull, B.C., Hicks, G.R.F. and Wells, J.B.J. (1981) Nematode/Copepod Ratios for Monitoring Pollution: A Rebuttal. Marine Pollution Bulletin, 12, 378-381.

[36] Raffaelli, D. (1987) The Behaviour of the Nematode/Copepod Ratio in Organic Pollution Studies. Marine Environmental Research, 23, 135-152.

[37] Vilela, C.G., Batista, D.S., Baptista Neto, J.A. and Ghiselli, R.O. (2011) Benthic Foraminifera Distribution in a Tourist Lagoon in Rio de Janeiro, Brazil: A Response to Anthropogenic Impacts. Marine Pollution Bulletin, 62, 2055-2074.

[38] Losi, V., Moreno, M., Gaozza, L., Vezzulli, L., Fabiano, M. and Albertelli, G. (2013) Nematode Biomass and Allometric Attributes as Indicators of Environmental Quality in a Mediterranean Harbour (Ligurian Sea, Italy). Ecological Indicators, 30, 80 89.

[39] Kress, N., Herut, B. and Galil, B.S. (2004) Sewage Sludge Impact on Sediment Quality and Benthic Assemblages off the Mediterranean Coast of Israel-A Long-Term Study. Marine Environmental Research, 57, 213-233.

[40] Harris, J.M. and Vinobaba, P. (2013) Assessment the Present Status of Batticaloa Lagoon, Sri Lanka by Means of Water Quality, Fish Diversity Indices and Pollution Indicating Planktons. Journal of Biodiversity \& Endangered Species, 1.

[41] Ormond, F.G.R., Gage, D.J. and Angel, V.M. (1997) Marine Biodiversity: Patterns and Processes. Cambridge University Press, Cambridge.

https://doi.org/10.1017/CBO9780511752360

[42] McLachlan, A. and Brown, A. (2006) The Ecology of Sandy Shores. 2nd Edition, Elsevier Ltd., London.

[43] Moodleyl, L., Chen, G., Heipl, C. and Vincx, M. (2000) Vertical Distribution of Meiofauna in Sediments from Contrasting Sites in the Adriatic Sea: Clues to the Role of Abiotic versus Biotic Control. Ophelia, 53, 203-212. 
Submit or recommend next manuscript to SCIRP and we will provide best service for you:

Accepting pre-submission inquiries through Email, Facebook, LinkedIn, Twitter, etc. A wide selection of journals (inclusive of 9 subjects, more than 200 journals)

Providing 24-hour high-quality service

User-friendly online submission system

Fair and swift peer-review system

Efficient typesetting and proofreading procedure

Display of the result of downloads and visits, as well as the number of cited articles Maximum dissemination of your research work

Submit your manuscript at: http://papersubmission.scirp.org/

Or contact ojms@scirp.org 